\title{
Persepsi Masyarakat tentang Agroforestri di Desa Sumberejo Poncokusumo Malang
}

\author{
Adi Suryo Purnomo ${ }^{1 *}$, Saimul Laili ${ }^{2}$, Hasan Zayadi ${ }^{3}$ \\ 1,2,3Program Studi Biologi Fakultas Matematika dan Ilmu Pengetahuan Alam Universitas Islam Malang, Indonesia. \\ *) Koresponden Penulis : adisuryo1192@gmail.com
}

\begin{abstract}
ABSTRAK
Agroforestri dalam Bahasa Indonesia, dikenal dengan istilah Wanatani atau agroforestri arti sederhananya adalah menanam pepohonan di lahan pertanian. agroforestri dikelompokkan menjadi dua sistem, yaitu sistem agroforestri sederhana dan sistem agroforestri kompleks. Tujuan penelitian ini mengetahui jenis jenis agroforestri serta mengetahui persepsi masyarakat tentang agroforestri di Desa sumberejo menggunakan metode deskriptif kuantitatif dan survey langsung di lapang. Penelitian dilakukan menggunakan metode deskriptif kuantitatif dan survei langsung di lapang dengan teknik wawancara semi terstuktur, membagikan kuesioner kepada responden. Data yang di dapatkan berupa gambar di peroleh melalui observasi secara langsung dilokasi penelitian, pada hasil survei jenis jenis agroforestri Desa Sumberejo terdapat 2 jenis agroforestri. Dari eksplorasi yang dilakukan ditemukan 27 jenis tanaman penyokong (penaung dan selingan) terdiri dari pohon dan tanaman komoditi lainnya. Pada hal ini problem masyarakat perkebun desa sumberejo dari yang kami wawancara langsung mengeluhkan minimnya pengetahuan tentang tanaman yang sesuai untuk agroforestri serta pengetahuan tentang pembenihan dan tanaman penyangga. Berdasar kan nilai persentase persepsi masyarakat Dusun Wonokerto dan Dusun Jajang nilai tertinggi sama sama 93\% terkait masalah sistem tanam campur, sedangkan pada nilai persentase terendah terdapat pada pengetahuan tentang angroforestri $79 \%$ di Dusun Jajang dan pada persepsi di Dusun wonokerto $80 \%$.
\end{abstract}

Kata kunci:, Agroforestri, Persepsi, Masyarakat

\begin{abstract}
Agroforestry in Indonesian, known as Wanatani or agroforestry, means simply planting trees on agricultural land. agroforestry is grouped into two systems, namely simple agroforestry systems and complex agroforestry systems. The purpose of this study was to determine the types of agroforestry and to find out the community perceptions of agroforestry in Sumberejo Village using quantitative descriptive methods and direct field surveys. The study was conducted using quantitative descriptive methods and direct surveys in the field with semi-structured interview techniques, distributing questionnaires to respondents. The data obtained in the form of images were obtained through direct observation at the location of the study, in the results of the survey of the types of agroforestry in Sumberejo Village there were 2 types of agroforestry. From the exploration carried out found 27 types of supporting plants (shade and interlude) consisting of trees and other commodity crops. In this case the problem of the Sumberejo village plantation community from the one we interviewed directly complained about the lack of knowledge about plants suitable for agroforestry and knowledge about hatcheries and buffer plants. Based on the value of the perceptions of the percentage of the Wonokerto and Jajang Hamlet communities the highest score was $93 \%$ related to the mixed cropping system, while the lowest percentage value was found in the knowledge about $79 \%$ in Jajang Hamlet and $80 \%$ in the Wonokerto Hamlet perception
\end{abstract}

Keywords: Agroforestry, Perception, Society

doi: $10.33474 /$ e-jbst.v7i2.313

Diterima tanggal 30 Juli 2019- Diterbitkan Tanggal 28 Januari 2022 http://creativecommons.org/licenses/by/4.0 


\section{Pendahuluan}

Upaya mengatasi kebutuhan akan lahan pertanian dengan tetap mempertahankan fungsi hutan dan lingkungan adalah melalui penerapan sistem agroforestri [1]. Menurut Model agroforestri yang sudah berkembang di Indonesia salah satunya yaitu agroforestri berbasis kopi. Model agroforestri ini mampu menyediakan layanan ekosistem yang hampir sama dengan hutan dan pada saat yang sama dapat memenuhi kepentingan sosial, ekonomi dan ekologi (konservasi) [2].

Agroforestri di Indonesia telah banyak di lakukan dengan berbagai nama yang berbeda di tiap daerah seperti di Kalimantan Barat disebut Tembawang untuk sistem agroforestri tradisional dilakukan pada saat petani akan melakukan perladangan berpindah untuk mencari lokasi lain yang lebih subur. Pada lahan yang ditinggalkan akan ditanamani berbagai jenis tanaman buah-buahan yang akan menjadi kebun [3].

\section{Material dan Metode}

\section{Bahan dan Alat}

Penelitian ini menggunakan alat dan bahan yaitu kuesioner untuk mendapatkan data pemahan dari masyarakat atau responden, kamera digital sebagai alat untuk dokumentasi, alat tulis menulis. sumber utama (key person) dalam penelitian ini sebagai salah satu petani. Sedang bahan yang digunakan dalam penelitian ini adalah jenis-jenis agroforestri di Dusun Jajang dan Wonokerto, Desa Sumberejo, Kecamatan Poncokusumo, Kabupaten Malang.

\section{Metode}

Penelitian ini menggunkan metode penelitian deskriptif kuantitatif dan survei langsung di lapang. survei merupakan teknik pengumpulan data yang spesifik dibandingkan teknik yang lain [4]. Penelitaian ini dilakukan dengan teknik wawancara semi terstruktur, melakukan teknik wawancara semi terstruktur dan diskriptif kuantitatif dengan intervew membagikan kuisioner kepada responden. Kegitan intervew perlu untuk memahami partisipan dengan benar sehingga dapat dijadikan pemandu dalam membuat penafsiran maupun kesimpulan yang berkenaan dengan informasi yang diberikan. Selanjutnya metode deskriptif kuantitatif yaitu dengan mendiskripsikan jenis-jenis agroforestri dan menggali informasi dari masyarakat. Data yang didapatakan berupa data dan gambar yang diperoleh melalui observasi secara langsung dilokasi penelitian.

\section{Hasil dan Diskusi}

Hasil Persepsi Masyarakat tentang jenis Agroforestri: Pada Hasil Persepsi Jenis Agroforestri di Dusun Jajang dan Dusun Wonokerto Desa Sumberejo terdapat 2 jenis agroforestri yaitu : Agroforestri sederhana dan Agroforestri komplek di Dusun Wonokerto dan juga Dusun Jajang yaitu: Pertama, sistem agroforestri sederhana ialah menanam pohon dilahan pertanian ditumpangsari kan dengan satu atau beberapa jenis tanaman biasanya lahan yang dikelola berada tidak terlalu jauh dari rumah. Kedua, sistem agroforestri komplek merupakan sistem pertanian yang sudah menetap dengan landscape atau tampak muka menyerupai hutan dimana keanekaragaman jenis nya beragam ditandai dengan ciri fisik dan dinamika didalam nya menyerupai hutan primer atau pun sekunder. Dalam sistem ini masyarakat tetap mempertahan kan semua jenis baik yang sengaja ditanam atau pun yang tumbuh sendiri

Tanaman utama: Masyarakat Dusun Jajang dan Dusun Wonokerto Jagung, kopi, cabai, tebu, singkong

Jenis-jenis tanaman penyokong agroforestri: Tanamam penyokong agroforestri berperan sebagai selingan, berperan menjaga kesetabilan iklim mikro, suhu udara dan kelembapan dalam kebun.

Identifikasi Jenis-jenis tanaman agroforestri: Dalam penelitian setelah melakukan survey dan eksplorasi, terdapat sejumlah tanaman yang teridentifikasi sebagai penunjang dalam sistem wanatani atau agroforestri di 
Dusun Jajang dan Dusun Wonokerto Desa sumberejo terdapat 27 tanaman yang terdapat di area tersebut di antaranya Pohon waru Hibiscus tiliaceus, Kelor Moringa oleifera, Rambutan Nephelium lappaceum, Sirsak Annona muricata, Alpukat Persea Americana, Asam jawa Tamarindus indica, Bambu apus Gigahntochloa apus, Cabai Capsicum annuum, Jagung Zea mays, Pohon jati Tectona grandis, Pohon Jati putih Gmelina arborea Roxb. Kluwih Artocarpus camansi, Nangka Artocarpus heterophyllus, Pepaya Carica Papaya, Petai Parkia Speciosa Hassk, Pinus Pinus merkusii, Pisang Musa paradisiaca, Rumput Gajah Pennisetum purpureum Schaum, Pohon Randu Ceiba pentandra, Pohon Sengon Paraserianthes falcataria, Singkong Manihot utilisima, Talas Colocasia esculenta Scho, Tomat Lycopersicum esculentum, Genitu Chrysophyllum cainito, Mahoni Swietenia macrophylla, Lamtoro Leucaena leucocephala, Sukun Artocarpus altilis.

Jenis -jenis agroforestri di Dusun Jajang dan Dusun Wonokerto: Dalam penelitian ini dilakukan eksplorasi untuk mengetahui Jenis -jenis agroforestri di Dusun Jajang dan Dusun Wonokerto Terdapat tiga tipe, utama agroforestri meliputi: Agrisilvikultur, Silvopastoral, Agrosilvopastura. Agrisilvikultur adalah perpaduan antara pertanian atau tanaman semusim seperti jagung, kopi, cabai, tebu, singkong dan juga tanaman hutan oleh masyarakat setempat dianggap memiliki banyak manfaat tidak hanya sebagai tanaman pendukung saja. Silvopastoral : Padang rumput/makanan ternak dan pohon, lahan hutan dikelola untuk memproduksi hasil kayu dan sekaligus memelihara ternak. Sebagian masyarakat tidak lepas dari peternakan yang saling bersinergi dilahan desa baik milik perorangan atau yang berada disekitar lingkungan desa. Agrosilvopastural adalah perpaduan di ketiga kategori yaitu tanaman pertanian, tanaman berkayu dan juga ternak, dengan mengkombinasikan ketiga kategori tersebut memberi manfaat jangka panjang maupun jangka pendek tak hanya manfaat kesejahtraan masyarakat dalam hal ini perekonomian namun dengan menanam pohon di lahan pertanian memberikan mafaat konservasi alam dapat dilihat dari fungsi pohon sebagai penaung, penahan angin, pengatur suhu serta dapat digunakan sebagai penghasil bahan bangunan.

Sistem agroforestri: Sistem agroforestri yang ada didusun wonokerto dan juga dusun jajang ialah sistem agroforestri yaitu sistem agroforestri sederhana dan sistem agroforestri kompleks. Sistem agroforestri sederhana adalah menanam pohon dilahan pertanian yang ditumpangsari kan dengan 2,3,4 sampai lima jenis tanaman beberapa jenis lahan yang dikelola berada tidak terlalu jauh dari rumah. Sistem agroforestri kompleks yaitu sistem dengan pola pertanian yang sudah menetap dengan landscape menyerupai hutan dimana keanekaragaman jenis nya beragam lebih dari 5 jenis tanaman dengan ciri fisik dan dinamika didalam nya menyerupai hutan primer dan sekunder. Dalam sistem ini masyarakat tetap mempertahan kan semua jenis baik yang sengaja ditanam atau pun yang tumbuh sendiri

Pola model yang biasa digunakan masyarakat Dusun Jajang dan Dusun Wonokerto ialah Pola pohon ditanam dipinggir - pinggir lahan pohan sebagai pagar dari lahan dengan kombinasi 2,3,4,5 tanaman. Selanjutnya Pola lajur ialah tanaman penaung berada dikiri dan dikanan tanaman utama, Pola berseling ialah tanaman pohon disisipkan disela-sela tanaman hortikultura, Pola acak dimana tanaman ditanam tak beraturan atau bercampur dari berbagai jenis tanaman sehingga menyerupai hutan baik hutan perimer atau hutan skunder dimana jenis tanaman yang tumbuh liar masih dipertahan kan karna masih memiliki kegunaan seperti rumput yang masih bias digunakan untuk pakan ternak, pohon dimana bias digunakan sebakgai kayu bakar.

Nilai Persepsi masyarakat Dusun Jajang dan Dusun Wonokerto Desa Sumberejo Berdasarkan tanggapan responden terhadap pertanyaan kuesioner tentang agroforestri di Dusun Jajang dan Dusun Wonokerto Desa Sumberejo Kecamatan Poncokusumo Kabupaten Malang. Dalam penelitian ini yang digunakan adalah 50 responden dari para petani dan masyarakat di Dusun Jajang dan Wonokerto yang kurang lebih berjumlah 500 kk, diambil 25 responden di Dusun Jajang nilai persepsi tanggapan masyarakat pada item pertanyaan menunjukan harapan dari nilai tinggi dengan harapan sangat tinggi dapat dilahat dari nilai skala pada item soal pertanyaan 1). $79 \%, 2$ ). $84 \%, 3) .93 \%, 4) .89 \%, 5) .89 \%, 6) .87 \%, 7) .83 \%$ 8). $83 \%$ 9). 91\%, 10).86\%, 11).88\%, 12).88\% dan 13). $89 \%$ nilai terrendah menunjukkan $79 \%$ dan nilai tertinggi menujukkan $93 \%$. Dusun Wonokerto diambil 25 responden menunjukkan nilai persepsi tanggapan masyarakat pada item pertanyaan menunjukan harapan dari nilai tinggi dengan harapan sangat tinggi dapat dilahat dari nilai skala pada item soal pertanyaan 1).80\%, 2).81\%, 3). $93 \%$, 4).89\%, 5).88\%, 6).85\%, 7).81\%, 8).86\%, 9).89\%, 10).85\%, 11).87\%, 12).88\% dan 13).84\% dengan nilai terendah menunjukkan $80 \%$ dan nilai tertinggi $93 \%$. 
e-Jurnal Ilmiah BIOSAINTROPIS (BIOSCIENCE-TROPIC)

Volume 7/ No.: 2 / Halaman 9-14 / Januari Tahun 2022

ISSN : 2460-9455 (e) - 2338-2805(p)

Persepsi masyarakat dari kedua dusun jajang dan wonokerto

Tabel 5. Persentase Perepsi Masyarakat terhadap Jawaban Kuesioner :

No Kuesioner

Dusun Wonokerto Dusun Jajang

1. Apakah Bapak/Ibu/Saudara

\begin{tabular}{llll}
$\begin{array}{l}\text { Skala } \\
\text { persentas } \\
\text { e \% }\end{array}$ & Kategori & $\begin{array}{l}\text { Skala } \\
\text { persentase } \\
\%\end{array}$ & kategori \\
\hline $80 \%$ & $\begin{array}{l}\text { Sangat } \\
\text { tinggi }\end{array}$ & $79 \%$ & $\begin{array}{l}\text { Sangat } \\
\text { tinggi }\end{array}$ \\
\hline
\end{tabular}
agroforestri?

2. Apakah Bapak/Ibu/Saudara mengetahui jenis-jenis agroforestri (tumpangsari) yang ada di desa sumberejo kecamatan poncokusumo kabupaten malang?

3. Apakah Bapak/Ibu/Saudara mengetahui sistem tanam campur antara tanaman hutan dan juga tanaman pertanian (sayur)?

4. Apakah Bapak/Ibu/Saudara mengetahui sistem tanaman, pertanian dan juga peternakan?

$\begin{array}{llll}81 \% & \begin{array}{l}\text { Sangat } \\ \text { tinggi }\end{array} & 84 \% & \begin{array}{l}\text { Sangat } \\ \text { tinggi }\end{array}\end{array}$

$\begin{array}{llll}93 \% & \begin{array}{l}\text { sangat } \\ \text { tinggi }\end{array} & 93 \% & \begin{array}{l}\text { Sangat } \\ \text { tinggi }\end{array}\end{array}$

5. Apakah Bapak/Ibu/Saudara mengetahui sistem campur hutan dan juga peternakan?

6. Apakah Bapak/Ibu/Saudara pernah menanam dengan sistem pekarangan?

$\begin{array}{lll}89 \% & \text { sangat } & \text { Sanga } \\ \text { tinggi } & 88 \% & \text { tinggi }\end{array}$

\begin{tabular}{|c|c|}
\hline $88 \%$ & $\begin{array}{l}\text { sangat } \\
\text { tinggi }\end{array}$ \\
\hline
\end{tabular}

$\begin{array}{llll}85 \% & \begin{array}{l}\text { Sangat } \\ \text { tinggi }\end{array} & 87 \% & \begin{array}{l}\text { Sangat } \\ \text { tinggi }\end{array}\end{array}$

7. Apakah Bapak/Ibu/Saudara mengetahui jarak tanam pada kebun campur?

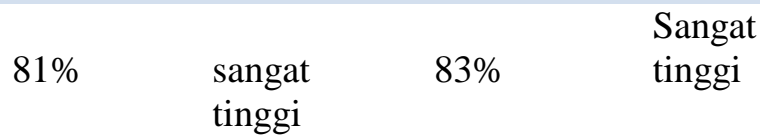

8. Apakah Bapak/Ibu/Saudara saudara mengetahui cara budidaya tanam campur dan juga pengembangan hewan

$\begin{array}{lll}\text { sangat } & 88 \% & \begin{array}{l}\text { Sangat } \\ \text { tinggi }\end{array}\end{array}$
ternak?

9. Apakah Bapak/Ibu/Saudara saudara mengetahui kombinasi tanaman sayur dengan tanaman kayu dan juga hewan ternak?

$\begin{array}{llll}89 \% & \begin{array}{l}\text { sangat } \\ \text { tinggi }\end{array} & 91 \% & \begin{array}{l}\text { Sangat } \\ \text { tinggi }\end{array}\end{array}$

10. Apakah masyarakat Desa sumberejo mengetahui bahwa perkebunan agroforestri dapat menjaga kondisi ekosistem $85 \%$

$\begin{array}{lll}\text { sangat } & 86 \% & \begin{array}{l}\text { Sangat } \\ \text { tinggi }\end{array}\end{array}$
tanah dan air? 


\begin{tabular}{|c|c|c|c|c|c|}
\hline 11. & \begin{tabular}{lrr} 
Apakah & \multicolumn{2}{c}{ Bapak/Ibu/Saudara } \\
setuju dengan & sistem \\
perkebunan & hutan \\
(Agroforestri)? &
\end{tabular} & $87 \%$ & $\begin{array}{l}\text { sangat } \\
\text { tinggi }\end{array}$ & $88 \%$ & $\begin{array}{l}\text { Sangat } \\
\text { tinggi }\end{array}$ \\
\hline 12. & $\begin{array}{l}\text { Apakah Bapak/Ibu/Saudara } \\
\text { saudara mengetahui manfaat } \\
\text { sistem tanam agroforestri? }\end{array}$ & $88 \%$ & $\begin{array}{l}\text { sangat } \\
\text { tinggi }\end{array}$ & $88 \%$ & $\begin{array}{l}\text { Sangat } \\
\text { tinggi }\end{array}$ \\
\hline 13. & $\begin{array}{l}\text { Apakah Bapak/Ibu/Saudara } \\
\text { pernah mencoba beralih dari } \\
\text { perkebunan campur dengan } \\
\text { perkebunan yang lain? }\end{array}$ & $84 \%$ & $\begin{array}{l}\text { sangat } \\
\text { tinggi }\end{array}$ & $89 \%$ & $\begin{array}{l}\text { Sangat } \\
\text { tinggi }\end{array}$ \\
\hline
\end{tabular}

Persepsi masyarakat dari kedua dusun jajang dan wonokerto Untuk mempermudah dalam memahami hasil persentase jawaban pemahaman masyarakat tentang item pertanyaan responden dapat dilihat pada gambar dibawah ini:

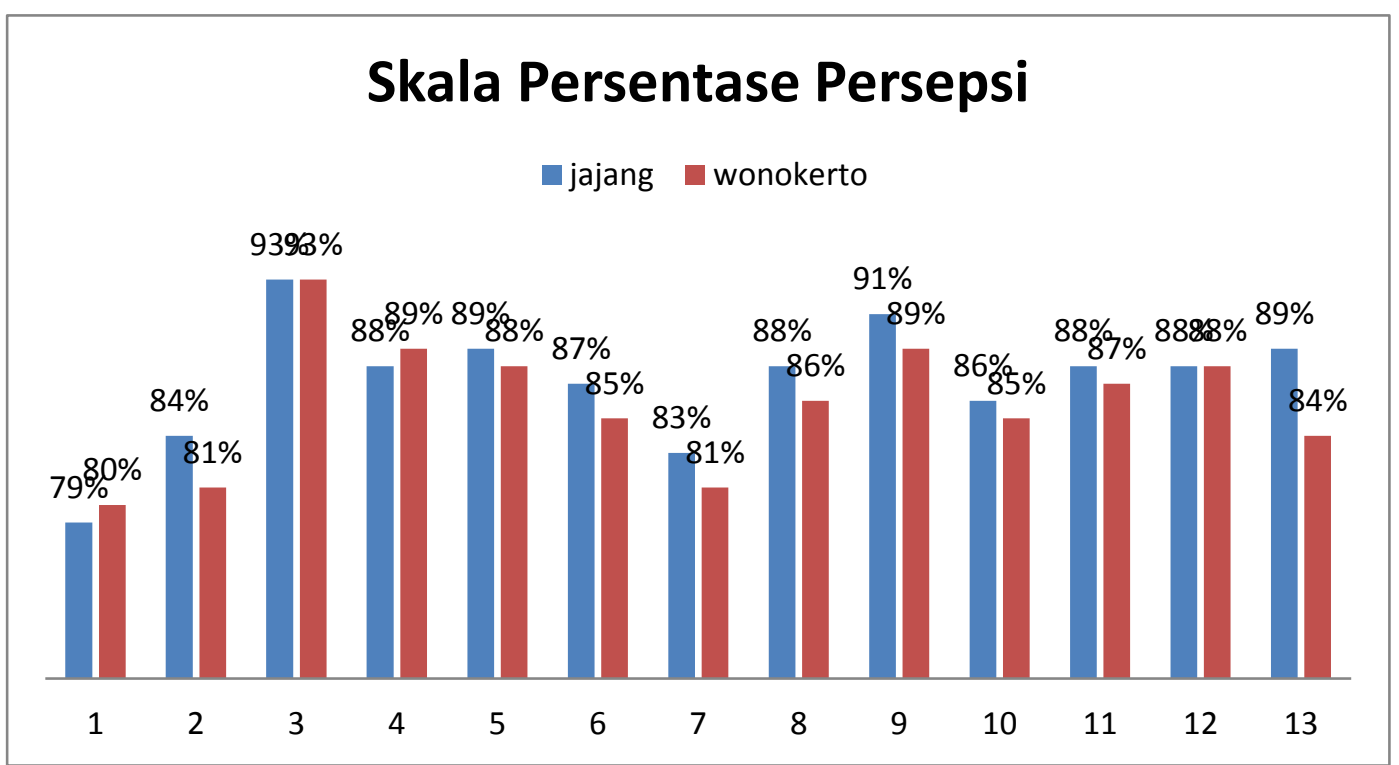

Gambar Perbandingan persepsi terhadap dua Dusun: Berdasarkan hasil gambar grafik persentase (\%) persepsi masyarakat terhadap pertanyaan tentang agroforestri didusun jajang menyatakan bahwa presentase persepsi masyarakat pada pertanyaan kuesioner 1 terkait pengetahuan masyarakat tentang agroforestri masuk dalam kategori sangat tinggi hal ini dapat diketahui pada nilai persentase jawaban $79 \%$, sedangkan di dusun wonokerto berada satu tingkat lebih tinggi yaitu $80 \%$ pada nilai persepsi jawaban dari pertanyaan tentang pengetahuan agroforestri, untuk mengetahui seberapa besar persepsi masyarakat dapat digunakan tabel persen tase jawaban kuesioner di mana kategori sanggat tinggi dapat diketahui dari $76-100 \%$, dari hasil diatas dapat diketahui pengetahuan masyarakat dusun jajang dan dusun wonokerto sanggat tinggi hanya berbeda satu persen. pada pertanyaan kuesioner terkait pengentahuan masyarakat tentang jenis jenis agroforestri sangat tinggi di dusun jajang yaitu $84 \%$ sedang kan pada dusun wonokerto $81 \%$ dikarenakan kedua dusun mayoritas masyarakat nya bertani, sedangkat persepsi masyarakat pada sistem tanam campur tanaman sejenis dan juga tanaman hutan sama sama sangagat tinggi dengan skala persentasi 93\%, pengetahuan masyarakat pada sistem tanam campur antar pertanian dan juga peternakan pada dusun jajang $88 \%$ dan dusun wonokerto $89 \%$ dengan artian pengetahuan masyarakat tentang peternakan dan pertaniaan sangat tinggi, persentase jawaban pertanyan masyarakat dusun wonokerto dan dusun jajang sanggat tinggi yaitu 88 dan $89 \%$ karena letak nya tidak jauh dari hutan sehingga masyarakat memanfaatkan hutan untuk peternakan, sedangkan persepsi masyarakat tentang pengalaman terkait pernah atau tidak nya sistem 
tanam pada kebun pekaranggan sangat tinggi dengan $83 \%$ di dusun jajang dan $85 \%$ di dusun wonokerto dengan artian peman faatan pekaranggan lebih tinggi di dusun jajang, pada pengaturan jarak tanam di kebun campur mastyarakat dusun jajang $83 \%$ dusun wonokerto $81 \%$ pengetahuan jarak tanam di kedua dusun sangat tinggi hanya berbeda tingkat pada persentase nya, sedang pengetahuan masyarakat terhadap sistem tanam campur tiga kategori ya itu pertanian, tanaman pohon dan juga pengembangan hewan sanggat tinggi untuk dusun wonokerto $89 \%$ dua tinggkat dibawah dusun jajang dengan persentase $91 \%$.

Pengetahuan masyarakat terhadap pertanyaan kuesioner tentang manfaat agroforestri untuk menjaga kondisi tanah dan dapat pula sebagai penyimpan air, persepsi masyarakat dusun wonokerto $85 \%$ dan masyarakat dusun jajang $86 \%$ dengan kategori sanggat tinggi. Dari hasil yang didapat tentang apa saja jenis agroforestri di Dusun Jajang dan Dusun Wonokerto Desa Sumberejo, Kecamatan Poncokusumo, Kabupaten Malang, didapatkan hasil dari kedua dusun tersebut tingakat persentase setiap dusun sangat tinggi dalam artian kedua dua dusun tersebut sama-sama memiliki 2 jenis agroforestri dan pengetahuan mereka terhadap jenis agroforestri sangat tinggi dengan persentase sebesar 80-93\%, dan untuk bagaimana persepsi masyarakat tentang agroforestri di Dusun Jajang dan Dusun Wonokerto, Desa Sumberejo, Kecamatan Poncokusumo, Kabupaten Malang dari kedua dusun tersebut juga memiliki angka sangat tinggi dengan persentase sebesar $80-93 \%$ dari setiap responden yang menjawab persepsi tersebut

Kesimpulan (Jika ingin dipisah dari Hasil dan Diskusi)

Pada penelitian ini dapat di simpulkan bahwa persepsi masyarakat tentang agroforestri sangat tinggi yang mana dari kedua dusun tersebut ditandai persentase sebesar $80-93 \%$ dan untuk persepsi masayarakat sendiri persentase besaran persepsi hamper sama dengan persepsi jenis agroforestri yang sama-sama memiliki nilai sangat tinggi

\section{Daftar Pustaka}

[1] Sabiarnurdin, S. 2011. Pendahuluan, Prinsip Produktivitas, Keserbagunaan Pohon dan Interaksi antar Komponen. Yogyakarta. Fakultas Kehutanan Universitas Gajah Mada.

[2] Prasmatiwi, F.E., Irham, A. Suryantini, dan Jamhari. 2010. Analisis keberlanjutan usahatani kopi di kawasan hutan Kabupaten Lampung Barat dengan pendekatan nilai ekonomi lingkungan. Pelita Perkebunan 26(1) : 57-69.

[3] Roslinda. 2010. Strategi Pengelolaan Tembawang Oleh Masyarakat.. Prosiding Agroforestri Tradisional di Indonesia. Bandar Lampung. Hal 159-166.

[4] Sugiono. 2011. Metode Penelitian Kuantitatif dan Kualitatif. Alfabeta. Bandung 